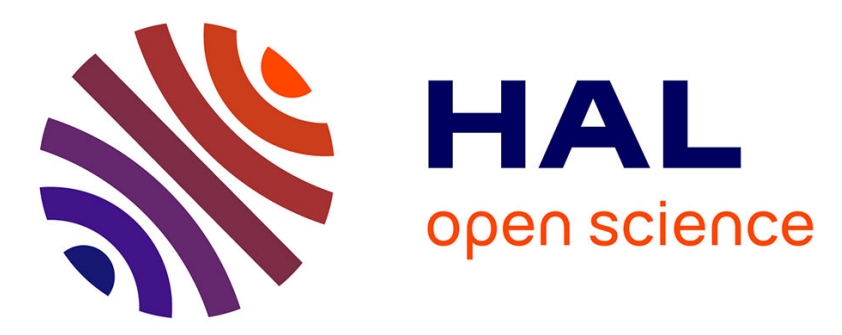

\title{
Latency of Herpes simplex virus type-1 in human geniculate and vestibular ganglia is associated with infiltration of CD8+ T-cells
}

Diethilde Theil

\section{- To cite this version:}

Diethilde Theil. Latency of Herpes simplex virus type-1 in human geniculate and vestibular ganglia is associated with infiltration of CD8+ T-cells. Journal of Medical Virology, 2010, 82 (11), pp.1917. 10.1002/jmv.21904 . hal-00599785

\section{HAL Id: hal-00599785 \\ https://hal.science/hal-00599785}

Submitted on 11 Jun 2011

HAL is a multi-disciplinary open access archive for the deposit and dissemination of scientific research documents, whether they are published or not. The documents may come from teaching and research institutions in France or abroad, or from public or private research centers.
L'archive ouverte pluridisciplinaire HAL, est destinée au dépôt et à la diffusion de documents scientifiques de niveau recherche, publiés ou non, émanant des établissements d'enseignement et de recherche français ou étrangers, des laboratoires publics ou privés. 


\section{Latency of Herpes simplex virus type-1 in human geniculate} and vestibular ganglia is associated with infiltration of CD8+ T-cells

\begin{tabular}{|r|l|}
\hline Journal: & Journal of Medical Virology \\
\hline Manuscript ID: & JMV-10-1789.R2 \\
\hline Wiley - Manuscript type: & Research Article \\
\hline Date Submitted by the \\
Author: & 23-Jun-2010 \\
\hline Complete List of Authors: & Theil, Diethilde; Klinikum Grosshadern, Clinical Neuroscience \\
\hline Keywords: & cranial ganglia, qRT-PCR, LAT \\
\hline
\end{tabular}

\section{今 scholarONE" \\ Manuscript Central}


Latency of Herpes simplex virus type-1 in human geniculate and vestibular ganglia is associated with infiltration of CD8+ T-cells

Arbusow Viktor ${ }^{1}$, Derfuss Tobias ${ }^{2}$, Held Kathrin ${ }^{3}$, Himmelein Susanne ${ }^{3}$, Strupp Michael $^{4}$, Gurkov Robert ${ }^{5}$, Brandt Thomas ${ }^{3}$ and Theil Diethilde ${ }^{3}$

${ }^{1}$ Clinic of Neurology am Marienplatz, Munich, Germany

${ }^{2}$ Department of Neurology, University of Erlangen, Erlangen, Germany

${ }^{3}$ Department of Clinical Neurosciences, Klinikum Grosshadern, Ludwig-Maximilians University, Munich, Germany

${ }^{4}$ Department of Neurology, Klinikum Grosshadern, Ludwig-Maximilians University, Munich, Germany

${ }^{5}$ Department of Oto-Rhino-Laryngology, Head and Neck Surgery, Klinikum

Grosshadern, Ludwig-Maximilians University, Munich, Germany

Running Head: Herpesviruses and human sensory ganglia

Address for correspondence:

Diethilde Theil, DVM

Department of Clinical Neurosciences, Klinikum Grosshadern

Marchioninistr. 23, 81377 Munich, Germany

Telephone: ++49-89-7095-4816

Fax: ++49-89-7095-4805

E-mail: diethilde.theil@med.uni-muenchen.de 


\begin{abstract}
Herpes simplex virus type-1 latency and CD8+ T-cell occurence were investigated in the trigeminal, geniculate, and vestibular ganglia from seven deceased humans. The HSV-1 "latency-associated transcript" was assessed by in situ-hybridization and quantitative RT-PCR. Infiltration of CD8+ T-cell was detected by immunohistochemistry and quantitative RT-PCR.

The data show that HSV-1 latency and CD8+ T-cell infiltration are not solely confined to the trigeminal ganglia but can also occur in other cranial ganglia along the neuroaxis. However, the HSV-1 latency transcripts in the geniculate and vestibular ganglia were expressed at a very low level. The difference in CD8 transcript levels among HSV-1 latently infected trigeminal ganglia, geniculate, and vestibular ganglia was less conspicuous. Colocalisation of latent HSV-1 and CD8+ T-cells in geniculate and vestibular ganglia supports further the hypothesis that HSV-1 reactivation is possible in these ganglia and is the cause of Bell's palsy and vestibular neuritis.
\end{abstract}

Key words: cranial ganglia; qRT-PCR; LAT; CD8+ T-cells 


\section{Introduction}

Herpes virus simplex type-1 (HSV-1) has been linked to a variety of clinical syndromes of the nervous system. After primary infection of the epithelium (stomatitis aphtosa), HSV-1 enters the axon terminals and is carried by axonal transport to sensory neurons of the human cranial nerve ganglia, where it establishes lifelong latency. HSV-1 latency is characterized by restricted viral expression: an abundant expression of the latency-associated transcript (LAT) (Stevens et al., 1987) and very low amounts of immediate early (IE) genes (Kramer \& Coen, 1995; Derfuss et al., 2007). Findings from the HSV-1 mouse model and from humans suggest that a chronic inflammation accompanies HSV-1 latency in the trigeminal ganglia (Shimeld et al., 1995; Theil et al., 2003). Previous investigations revealed that the highest frequency of neurons, that were positive for the latency-associated transcript, is found in the human trigeminal ganglia. However, latency-associated transcripts were also present, although in lower amounts in the geniculate and vestibular ganglia (Theil et al., 2001). Decreasing amounts of the latency-associated transcript from the trigeminal ganglia to the geniculate and vestibular ganglia are compatible with the hypothesis that HSV-1 migrates along the lingual nerve to the trigeminal and geniculate ganglia and via the facio-vestibular anastomoses to the vestibular ganglia (Arbusow et al., 1999). A large post-mortem study on human trigeminal ganglia demonstrated that latent HSV-1 is accompanied by an abundant CD8+ T-cell infiltration (Theil et al., 2003). According to the HSV-1 mouse model, one would expect that in all ganglia, where HSV-1 becomes latent, there should also be a T-cell infiltration, since this is supposed to maintain the virus in its latent state (Khanna et al., 2003). However, given that symptomatic HSV-1 reactivations from human trigeminal ganglia occur very frequently in humans (cold sores), the prominent T-cell 
infiltration is possibly a consequence of continuing asymptomatic or symptomatic reactivations that are distinctive of the trigeminal ganglia.

The aim of the present study was to determine whether immune infiltration occurs in other cranial ganglia (geniculate and vestibular ganglia), which are known to also harbor latent HSV-1. An affirmative answer would indicate viral activity (e.g., symptomatic or asymptomatic reactivations). The presence of latency-associated transcript and T-cells in the geniculate and vestibular ganglia would affirm the hypothesis that HSV-1 reactivations are to be expected at this site and that they cause neurological entities like Bell's palsy and vestibular neuritis. 


\section{Material and Methods}

The Ethics Committee of the Medical Faculty of the Ludwig-Maximilians University of Munich has approved the use of autopsy samples for the present study. The cause of death of the subjects included in the study was related to trauma. None had lesions suggestive of an active orolabial herpes infection. There were no records that they had suffered from vestibular neuritis or any other neurological disorder during their lifetime.

The trigeminal, geniculate, and vestibular ganglia from seven individuals (ages 5 weeks to 40 years) were collected (Table 1A). Ganglia were embedded in Tissue tek $^{\circledR}$ compound (Sakura, Zoeterwoude, The Netherlands) and stored at $-70^{\circ} \mathrm{C}$ until use. Frozen sections were made of $8-\mu \mathrm{m}$ thickness and mounted on positively charged slides (SuperFrost ${ }^{\star} /$ Plus $^{\oplus}$, Menzel, Braunschweig, Germany). In parallel a number of tissue sections were collected for RNA extraction. Beforehand, tissue sections from each ganglion were stained with hematoxylin and eosin for morphologic examination and the RNA quality of each ganglion was evaluated.

For immunohistochemistry frozen tissue sections were thawed, dried at $37^{\circ} \mathrm{C}$ for 15 min, fixed in acetone for $10 \mathrm{~min}$, and then incubated overnight with mouse anti-CD8 antibody. Afterwards tissue sections were incubated for $30 \mathrm{~min}$ in biotinylated rabbit anti-mouse IgG antibody (1:500; DAKO, Hamburg, Germany). The sections were incubated with peroxidase-conjugated streptavidin (DAKO, Hamburg, Germany) for $30 \mathrm{~min}$, followed by a final wash, and then incubated with diaminobenzidine (DAB) (DAKO, Hamburg, Germany) for up to 10 min. For in-situ hybridization the protocol used was described in detail in a previous work (Theil, et al., 2001). The ISH signal was visualized by incubation in nitroblue tetrazolium (NBT) and X-phosphate (BCIP 5-bromo-4-chloro-3-indolyl-phophate) staining solution. 
RNA extraction and cDNA synthesis were performed using commercially available kits (miRNeasy Mini Kit, Qiagen, Hilden; high capacity cDNA reverse transcription kit, Applied Biosystems, Foster City, CA, USA) according to the manufacturers' protocols. To quantify latency-associated transcripts and CD8 transcripts QuantiTect SYBR $^{\circledR}$ green RT-PCR (Qiagen) was used on a GeneAmp 5700 Sequence Detection System (Applied Biosystems). The results were normalized to the housekeeping gene beta-actin. Primer and PCR conditions were published previously (Theil et al., 2003; Naoe et al., 2002; Derfuss et al., 2007).

The occurrence of latent HSV-1 and T-cell infiltration in the trigeminal ganglia from the subjects included in this study was assessed previously. HSV-1 latency was detected by in-situ hybridization and RT-PCR for the latency-associated transcript. Cytotoxic T-cells were detected by CD8 immunohistochemistry and quantitative RTPCR (Theil et al., 2003).

The trigeminal ganglia from one individual who showed strong positivity for the latency-associated transcript on in-situ hybridization and for T-cells on immunohistochemistry, and the trigeminal ganglia from another individual who was negative for the latency-associated transcript and T-cells were included as controls (references) for quantitation of the latency-associated transcripts and CD8 T-cells (Table 1 B). 


\section{Results}

Tissue sections and the RNA from all ganglia were checked beforehand for the presence of neurons in the section and for RNA integrity. Due to morphological artifacts and RNA degradation in some ganglia, measurement of CD8 transcripts was not possible in the ganglia from each side of the same individual. Latency-associated transcript and CD8 expression could however be assessed in at least one side of the trigeminal, geniculate, and vestibular ganglia of each individual (Table 1A).

Of the fourteen trigeminal ganglia tested by in situ hybridization or RT-PCR, 6 showed positivity for the latency-associated transcript with either method. None of the 10 geniculate and 11 vestibular ganglia showed a positive signal for the latencyassociated transcript when tested by in situ hybridization, but expression of the latency-associated transcript was detected at low levels by quantitative RT-PCR in the 2 vestibular and 2 geniculate ganglia from one individual (Table $1(A)$, subject 5 ). The transcripts levels in the control trigeminal ganglia were 1000x higher than in the geniculate and vestibular ganglia (Table 1, B).

Infiltration of CD8+ T-cells was detectable by immunohistochemistry only in the trigeminal ganglia (data published earlier) but not in the geniculate and vestibular ganglia (data not shown). By means of quantitative RT-PCR, CD8 transcripts were detectable in all tested trigeminal, geniculate, and vestibular ganglia. In the ganglia of three individuals the transcription levels of CD8 were clearly elevated (Table 1, subjects 5, 6 and 7). In these subjects the trigeminal ganglia were also positive for the latency-associated transcript, and in one subject (Table $1 \mathrm{~A}$, subject 5) even the geniculate and vestibular ganglia were positive for the latency-associated transcript. In the geniculate and vestibular ganglia, that were positive for the latency associated transcript, the CD8 transcript levels were analogous to the CD8 transcript level of the 
control trigeminal ganglia (Table 1B, control 1), although the latency-associated transcripts in the geniculate and vestibular ganglia were very low when compared to the levels in the trigeminal ganglia (Table 1B, control 1). 


\section{Discussion}

In the present study it was shown that CD8+ T-cells infiltrate human cranial ganglia other than the trigeminal ganglia. The CD8 transcript levels in the geniculate and vestibular ganglia that contained the latency-associated transcripts were comparable with the levels found in the trigeminal ganglia that were positive for the latencyassociated transcripts. These findings emphasize that HSV-1 latency is associated with chronic inflammation not only in the human trigeminal ganglia where frequent HSV-1 reactivation occurs but also in other ganglia linked anatomically (geniculate and vestibular ganglia). This is of clinical relevance, since it supports the view that Bell's palsy and vestibular neuritis are caused by reactivation of HSV-1. Up till now only the surrogate marker for HSV-1 latency, the latency-associated transcript, could be demonstrated in the geniculate and vestibular ganglia (Furuta et al., 1992; Furuta et al., 1993; Theil et al., 2001). Additional detection of CD8 T-cells in the HSV-1 latently infected geniculate ganglia and vestibular ganglia means that persistently or intermittently low levels of lytic gene expression occur in some neurons, and full reactivation is suppressed by CD8+ T-cells. However, for some unknown reason the protective role of CD8 T-cells can be abrogated and the virus then replicates, leading to a reactivating disease (e.g., Bell's palsy and vestibular neuritis).

Interestingly, the levels of CD8 transcripts in the geniculate and vestibular ganglia, which did not contain the latency-associated transcript but were obtained from subjects who showed positivity for the latency-associated transcript in the trigeminal ganglia, exceeded the values seen in the trigeminal, geniculate, and vestibular ganglia from individuals who had not had any HSV-1 infection. On the one hand, the elevated levels of CD8 in these ganglia could be due to a very low load of latent virus, which is below the sensitivity of the analytical method applied. On the other hand, the CD8+ T-cells might become sequestered at this site after a primary HSV-1 
infection has been cleared. Even though it is generally accepted that immune cells invade the trigeminal ganglia in the course of a primary infection and a certain CD8+ T-cell population persists thereafter in order to maintain the virus in a latent state by constant expression of effector molecules such as granzyme B and IFN-gamma (Liu et al., 2001; Bergstrom, 1973), T-cells could persist without depending on viral antigen to provide equipment for a second encounter with the virus. As a matter of fact, a recent study demonstrated that a unique memory T-cell pool remains resident in the skin well after HSV-1 has been cleared (Gebhardt et al., 2009). This CD8+ Tcell population does not seem to depend on ongoing viral gene expression, but shows preferential protection from a subsequent infection with HSV-1. Correspondingly, entrapment of CD8+ T-cells in the geniculate and vestibular ganglia without latent HSV-1 could stem from a cleared HSV-1 acute infection that encompassed all cranial ganglia or an anterograde infection during the course of HSV-1 reactivation in the trigeminal ganglia (Theil et al., 2001). These cells probably have the same protective capacity as those found in the skin of HSV-1 infected mice (Gebhardt et al., 2009) and humans (Zhu et al., 2007) and consequently limit viral spread to additional neurological structures. 


\section{Acknowledgements}

This work was supported by a grant from the Deutsche Forschungsgemeinschaft to D.T. and T.D. (TH 894/3-1). We would like to thank Judy Benson and Katie Ogston for carefully copyediting the manuscript. 


\title{
References
}

\begin{abstract}
Arbusow V, Schulz P, Strupp M, Dieterich M, von Reinhardstoettner A, Rauch E, Brandt T. 1999. Distribution of herpes simplex virus type 1 in human geniculate and vestibular ganglia: implications for vestibular neuritis. Ann Neurol 46:416-419.
\end{abstract}

Bergstrom B. 1973. Morphology of the vestibular nerve. I. Anatomical studies of the vestibular nerve in man. Acta Otolaryngol 76:162-172.

Derfuss T, Segerer S, Herberger S, Sinicina I, Hufner K, Ebelt K, Knaus HG, Steiner I, Meinl E, Dornmair K, Arbusow V, Strupp M, Brandt T, Theil D. 2007 Presence of HSV-1 immediate early genes and clonally expanded T-cells with a memory effector phenotype in human trigeminal ganglia. Brain Pathol 17:389-398.

Furuta Y, Takasu T, Fukuda S, Inuyama Y, Sato KC, Nagashima K. 1993. Latent herpes simplex virus type 1 in human vestibular ganglia. Acta Otolaryngol Suppl 503:85-89.

Furuta Y, Takasu T, Sato KC, Fukuda S, Inuyama Y, Nagashima K. 1992. Latent herpes simplex virus type 1 in human geniculate ganglia. Acta Neuropathol (Berl) 84:39-44.

Furuta Y, Takasu T, Suzuki S, Fukuda S, Inuyama Y, Nagashima K. 1997. Detection of latent varicella-zoster virus infection in human vestibular and spiral ganglia. J Med Virol 51:214-216. 
Gebhardt T, Wakim LM, Eidsmo L, Reading PC, Heath WR, Carbone FR. 2009.

Memory T cells in nonlymphoid tissue that provide enhanced local immunity during infection with herpes simplex virus. Nat Immunol 10:524-530.

Hufner K, Derfuss T, Herberger S, Sunami K, Russell S, Sinicina I, Arbusow V, Strupp M, Brandt T, Theil D. 2006. Latency of alpha-Herpes Viruses Is Accompanied by a Chronic Inflammation in Human Trigeminal Ganglia But Not in Dorsal Root Ganglia. J Neuropathol Exp Neurol 65:1022-1030.

Jacobsen M, Zhou D, Cepok S, Nessler S, Happel M, Stei S, Wilske B, Sommer N, Hemmer B. 2003. Clonal accumulation of activated CD8+ T cells in the central nervous system during the early phase of neuroborreliosis. J Infect Dis 187:963-973.

Khanna KM, Bonneau RH, Kinchington PR, Hendricks RL. 2003. Herpes simplex virus-specific memory CD8+ T cells are selectively activated and retained in latently infected sensory ganglia. Immunity 18:593-603.

Kramer MF, Coen DM. 1995. Quantification of transcripts from the ICP4 and thymidine kinase genes in mouse ganglia latently infected with herpes simplex virus. J Virol 69:1389-1399.

Liu T, Khanna KM, Carriere BN, Hendricks RL. 2001. Gamma interferon can prevent herpes simplex virus type 1 reactivation from latency in sensory neurons. J Virol $75: 11178-11184$

Naoe M, Marumoto Y, Ishizaki R, Ogawa Y, Nakagami Y, Yoshida H. 2002.

Correlation between major histocompatibility complex class I molecules and CD8+ T 
lymphocytes in prostate, and quantification of CD8 and interferon-gamma mRNA in prostate tissue specimens. BJU Int 90:748-753.

Shimeld C, Whiteland JL, Nicholls SM, Grinfeld E, Easty DL, Gao H, Hill TJ. 1995. Immune cell infiltration and persistence in the mouse trigeminal ganglion after infection of the cornea with herpes simplex virus type 1. J Neuroimmunol 61:7-16.

Stevens JG, Wagner EK, vi-Rao GB, Cook ML, Feldman LT. 1987. RNA complementary to a herpesvirus alpha gene mRNA is prominent in latently infected neurons. Science 235:056-1059.

Theil D, Arbusow V, Derfuss T, Strupp M, Pfeiffer M, Mascolo A, Brandt T. 2001. Prevalence of HSV-1 LAT in human trigeminal, geniculate, and vestibular ganglia and its implication for cranial nerve syndromes. Brain Pathol 11:408-413.

Theil D, Derfuss T, Paripovic I, Herberger S, Meinl E, Schueler O, Strupp M, Arbusow V, Brandt T. 2003. Latent herpesvirus infection in human trigeminal ganglia causes chronic immune response. Am J Pathol 163:2179-2184.

Theil D, Derfuss T, Strupp M, Gilden DH, Arbusow V, Brandt T. 2002. Cranial nerve palsies: herpes simplex virus type 1 and varizella-zoster virus latency. Ann Neurol $51: 273-274$.

Zhu J, Koelle DM, Cao J, Vazquez J, Huang ML, Hladik F, Wald A, Corey L. 2007. Virus-specific CD8+ T cells accumulate near sensory nerve endings in genital skin during subclinical HSV-2 reactivation. J Exp Med 204:595-603. 
Table $1(\mathrm{~A})$ : Quantitation of CD8 transcripts in human trigeminal, geniculate and vestibular ganglia from subjects whose trigeminal ganglia were either LAT negative or LAT positive

\begin{tabular}{|c|c|c|c|c|c|}
\hline \# Subjects & Age & Site & \multicolumn{3}{|c|}{ CD8 transcript levels } \\
\hline TG(LAT+/-) & & & $\begin{array}{c}\text { Trigeminal } \\
\text { Ganglia }\end{array}$ & $\begin{array}{c}\text { Geniculate } \\
\text { Ganglia }\end{array}$ & $\begin{array}{c}\text { Vestibular } \\
\text { Ganglia }\end{array}$ \\
\hline \multirow[t]{2}{*}{1 (LAT-) } & \multirow[t]{2}{*}{5 weeks } & Right & n.d. & 30.2 & 58.8 \\
\hline & & Left & 26.2 & 15.2 & 34.8 \\
\hline \multirow[t]{2}{*}{2 (LAT-) } & \multirow[t]{2}{*}{$1.5 \mathrm{mo}$} & Right & n.d. & 24.4 & 78.9 \\
\hline & & Left & 9.4 & n.d. & 71.2 \\
\hline \multirow[t]{2}{*}{3 (LAT-) } & \multirow[t]{2}{*}{9.0 months } & Right & 99.2 & 104.0 & 115.0 \\
\hline & & Left & n.d. & n.d. & 50.8 \\
\hline \multirow[t]{2}{*}{4 (LAT-) } & \multirow[t]{2}{*}{5 years } & Right & 134.5 & 79.8 & 88.6 \\
\hline & & Left & n.d. & n.d. & n.d. \\
\hline \multirow[t]{2}{*}{$5(\mathrm{LAT}+)$} & \multirow[t]{2}{*}{8 years } & Right & 410.6 & $271.3^{*}$ & $229.9^{*}$ \\
\hline & & Left & 388.4 & $296.8^{*}$ & $147.5^{*}$ \\
\hline \multirow[t]{2}{*}{$6(\mathrm{LAT}+)$} & \multirow[t]{2}{*}{40 years } & Right & 239.0 & 159.2 & 291.6 \\
\hline & & Left & n.d. & 166.9 & n.d \\
\hline \multirow[t]{2}{*}{$7(\mathrm{LAT}+)$} & \multirow[t]{2}{*}{37 years } & Right & 126.4 & 94.2 & 139.2 \\
\hline & & Left & n.d. & n.d. & n.d. \\
\hline
\end{tabular}

n.d. = not determined; LAT = latency-associated transcript; $T G=$ trigeminal ganglia ${ }^{*}$ The geniculate and vestibular ganglia from only this individual were positive for LAT when tested by TaqMan PCR. The LAT transcript levels ranged between 1 to 70 copies.

Table 1 (B): Quantitation of CD8 and LAT transcripts in human trigeminal ganglia (control tissue)

\begin{tabular}{l|l|l|ll}
\hline \# Subjects & Age & Site & \multicolumn{2}{|l}{ Trigeminal Ganglia } \\
\hline & & & \multicolumn{3}{|c}{ CD8 } \\
& & & transcript levels \\
\hline 1 & 41 years & Right & 219.7 & 1149.2 \\
& & Left & 406.2 & 2406.2 \\
\hline 2 & 62 years & Right & 78.8 & 0 \\
& & Left & 125.0 & 0 \\
\hline
\end{tabular}

The transcript levels represent the relative transcript number of the gene of interest (CD8 and LAT) compared to the housekeeping gene beta-actin. CD8 transcript levels ranging from 15 to 150 were considered part of the constitutive expression. 